\title{
Informal land use and environmental pollution in Ogbomoso
}

\author{
Jelili M. O.*, Ayankanmi J. A. and Odunola O. O. \\ Department of Urban and Regional Planning, Ladoke Akintola University of Technology Ogbomoso, Nigeria.
}

Received 16 September, 2017; Accepted 3 October, 2017

\begin{abstract}
Against the background of the contribution of the informal sector and/or land use to the urbanization process of the developing economies, especially in Africa, this paper examines the spatial distribution and environmental pollution implications of automobile workshops, as an important informal land use in Ogbomoso, Nigeria. Inventory of the locations of the workshops was done, and air, water and soil samples were taken from six of the workshops selected from different density areas of the town for tests on the presence and concentrations of pollutants, and the results compared with appropriate standards. The spatial distribution of the workshops was observably non-random, but have some environmental implications, noted especially in water samples (with concentrations of heavy metals such as lead and zinc higher than permissible levels) and air samples (with gaseous pollutants such as $\mathrm{CO}$ and $\mathrm{CO} 2$, among others, beyond permissible levels). The paper, however observes that the operators of the informal activity are responsible household heads with an average income higher than the national minimum wage, capable of contributing meaningfully to the urban and national economy. It is therefore recommended that the land use activity be integrated into the formal economy and land use planning by easing the required processes of establishing, registering, and operating the business outfits through implementation of relevant people-friendly policies. This, the paper argues, would also necessitate further studies on different other dimensions of formalizing the land use.
\end{abstract}

Key words: Informal land use, integration, urban planning.

\section{INTRODUCTION}

The issue of informality in the urbanization process of African communities, which has not been adequately understood or appreciated, is a clog in the wheel of progress, particularly with respect to sustainable development. While this informality question may not be peculiar to the developing nations, real development in all its ramifications, may elude African economies, whose informal component engages higher proportions of workforce than the formal one, and whose urbanization processes are much driven by different dimensions of informality. The spatial manifestation of this is in land use, which is a challenge to land use planning and urban land use planners, who find their plans always distorted by the less recognized and unregulated human activities.

*Corresponding author. E-mail: mojelili@lautech.edu.ng.

Author(s) agree that this article remain permanently open access under the terms of the Creative Commons Attribution License 4.0 International License 
Of particular concern is the fact that the informal activities are major sources of environmental pollution, which need be analyzed for effective control and physical planning purposes. A particular and highly visible category of the land use type is informal automobile workshops. Such issues as distribution, types, reasons for their location (where they are), specific impacts, and effective frameworks for the control and/or planning of informal workshops in a medium term town (like Ogbomoso, before it gets out of hand as witnessed in larger cities) are the questions agitating the mind of the land use planner.

\section{The problem}

The increasing urbanization level in Africa is an established phenomenon which shall continue into at least the foreseeable future (Jelili, 2012). As a particular characteristic of urbanization process in Africa, informality, expressed in all forms of less regulated urban land use activities and housing, among others, is a serious issue. A major category of this is informal automobile workshops, with their pollution potentials. As observed by Adewoyin et al. (2013), informal automobile workshops are associated with deliberate releases or discharge of petrol, diesel, solvents, grease, and lubricants on the land and in the atmosphere. These are substances that are toxic to humans and animals, and can as well pollute waterways directly or indirectly. More so, Bassuer (1987) observes that chemicals such as refrigerator gases used in vehicle air conditioners, and often released during maintenance work at these workshops, are made up of chlorofluoro-carbon, which is capable of depleting the ozone layer and causing a greenhouse effect. This is in line with the conclusion of Pollutionfree (2010) that automobile workshops emit large quantities of $\mathrm{CO}_{2}, \mathrm{Co}, \mathrm{PM}$ and substances known as mobile source air toxics (MSATs) such as benzene, formaldehyde, acetaldehyde, 1-3 butadiene, and lead, among others.

In view of the above, research attempts have been directed at unveiling the impact of this phenomenon on specific aspects of the environment. For example, Nwachukwu et al. (2010), Faronbi (2013), Adewoyin et al. (2013), Eludoyin et al. (2013) and Utang et al. (2013), among others establish the impact of informal automobile workshops on soil, surface and underground water. In the same vein, Wong and Lau (1985), Iwegbue (2007), Ipeaiyeda and Dawodu (2008), and Ekong (2012), among others, identify the link between informal automobile workshops' activities and atmospheric and environmental pollution generally.

The above, among others, provide an insight into the physicochemical properties of the substances released or discharged within or around the automobile workshops due to their maintenance and repair work, and the pollution impact of the same. Those attempts, no doubt, raise concern and consciousness about the likely health implications of the activities of the complex land use. It is, however, saying little or nothing about the reason why such land use activities are located where they are, their spatial distribution in relation to land use pattern or density, and socioeconomic factor that may be responsible for same. These are important variables that are necessary for effective planning and control towards reducing the negative impacts of the activities.

Research attempts at unveiling such relevant variables of physical planning importance are inadequate. While the works of Onyebueke and Geyer (2011), among others, provide the conceptual clarification and basic characteristics of the informal sector activities, those of Onyebueke (2000) and Okeke (2000) unveil the general characteristics and spatial distribution of informal sector activities, especially within residential areas, and establish the relationship between the phenomenon and density. Jelili and Adedibu (2006), in their attempt to give it a more spatial perspective, link the incidence of informal sector activities with road hierarchy and land use type, and observe that the activities are more along higher order roads than lower order ones, and more concentrated in and/or around commercial land use than within other land use types. The research efforts here, though from physical planning perspective, represent spatial dimension of informal sector activities in general, and not specifically on informal automobile workshops, which are the major informal sources of urban pollution. This is a challenge taken up by Jelili et al. (2017) in their analysis of spatial distribution and planning implication of informal automobile workshops in Osogbo, the capital of Osun State, Nigeria. The study observes a spatial distribution pattern that encourages springing up of the land use within and around any form of land use if left uncontrolled by effective planning and development control, and recommends establishment of workshop complex, called 'mechanic village'.

It is important to observe, however, that the situation observed in one town or city may not be the same in others, depending on the factor of spatial extent or human population size, urbanization level, being a state capital city or not, and socioeconomic and cultural factors, among others. In this study, the situation in a non-capital city, Ogbomoso, with perhaps different socioeconomic and urbanization level is examined. The study essentially provides answers to such questions as: (1) what is the spatial distribution of informal automobile workshops in the town?; (2) what are the specific pollution types that are associated with the informal automobile workshops?; and more importantly, (3) how can land use planning solutions be provided for effective integration of the land use into formal land use planning and control of the same towards safeguarding the health 
and well-being of the people?

\section{Purpose of the study}

The main aim is to examine the spatial distribution of informal automobile workshops (IAWs) and their environmental pollution impacts. This is with a view to identifying effective framework for the planning and control of the informal land use. The specific objectives are to: (1) examine the spatial distribution of IAWs; (2) evaluate the environmental impacts; (3) determine the socioeconomic implications of the activities of the IAWs; and (4) suggest land use planning framework and/or measures for integrating the land use into formal spatial planning.

\section{CONCEPTUAL FRAMEWORK: ENVIRONMENTAL MANAGEMENT, INFORMAL LAND USE AND PLANNING}

Environmental management refers to all procedures that are involved in the protection and improvement of human environment, basically for safeguarding the air, water and land, as well as the forest and wildlife, with the main goal of protecting and improving quality of human life. According to Uchegbu (1998), it is the process of putting together those items of environmental nature where man exists so that man's penetration and exploitation do not have adverse effects on the environment. It involves management of all components of the bio-physical environment (Juhasz and Szollosi, 2008) as well as the built or cultural environment, including the control of all human activities, which is of great concern here.

Human activities are spatially expressed as land use, which Essaghah (1997) simply puts as the use to which land is put. Land use is an expression of the complex interrelationships among different human activities and how they are distributed in space. However, one of the most disturbing problems of land use in urban areas is its classification (Jelili and Adedibu, 2006). This arises from the flexibility in the factors which produce land use pattern, and more importantly, due to the emerging dichotomy of formal and informal dimensions of land use.

Ordinarily, there should not be informal category (or informal land use) where land use planning and control is effective. Land use planning, which deals with the spatial ordering of human activities in a way to achieve harmony, economy and beauty, is expected to have resolved the conflict to be brought about by the emergence of informal land use, which in most, if not all, cases are nonconforming land use. This is because the process (of land use planning) ought to have classified all human activities into different primary (residential, commercial, industrial, etc) and secondary (residential density areas, classes of commercial use, types of industries, etc) uses before distributing them accordingly in space. This implies that the so called informal land use is a complex land use terminology, which refers to all forms of land use not recognized by the existing formal plan or other legal documents. Interestingly, however, many human activities in developing countries, especially in Nigeria, fall under this category of land use. They are described, according to UNDP (1986) as activities that "thrive in their thousands in the cities of the less developed countries, transforming them into beehives of minuscule enterprises all of which are pitched in stiff competition for dwindling space and patronage". Of much importance to environmental management, land use planning, and this study in particular, is IAWs' category, which constitute a significant proportion of informal land use in Ogbomoso and other towns and cities in Nigeria.

Automobile workshops or auto-workshops are repair shops where automobiles are repaired or maintenance work takes place by automobile artisans, technicians and/or engineers. The workshops specialize in certain areas such as break, muffler and exhaust systems, automobile electrification, air-conditioner and glass and general engine repairs and reinstallation, wheel alignment, painting, panel beating and vulcanizing, among others (Kayemuddin and Kayum, 2013). Because most of them, particularly in Nigeria, are located at undesignated places, unregistered and pay nothing as company tax, make use mostly of artisans and technicians (who are in most cases, sole proprietors of the IWAs) and unstable apprentice, and are described as informal automobile workshops. They, however, constitute a significant component of the urban economy in most towns and cities in the developing economies. Therefore, rather than make them continue aggravating the problem of distortion of land use plan (where any) and consequently aggravating the problem of environmental management, there is need for effective ways of integrating them into formal land use planning and environmental management system. This may continue to be a mirage, unless their spatial distribution pattern and environmental impacts of their activities are understood. This is the object of this study.

\section{METHODOLOGY}

\section{Study area}

The study area is Ogbomoso Township, covering Ogbomoso North and South Local Government Areas. Ogbomoso is a major town and second largest urban centre in Oyo State after Ibadan, the state capital. It lies approximately around $8^{\circ} 8^{\prime} \mathrm{N}$ of the Equator and $4^{\circ} 15^{\prime} \mathrm{E}$ of the Greenwich Meridian. As a gateway to the northern part of the country, it lies within the derived savanna region. The city has tropical wet and dry seasons, with the wet season starting from March to late October or early November, while the dry season, characterized with dry harmattan, starting from late 
November to February. The climate is characterized with a fairly high uniform temperature, high relative humidity and moderate to heavy seasonal rainfall.

As one of the fast growing cities in the Southwest of Nigeria, the spatial extent and human population of the town increased tremendously over time. The town, which started as a coalescence of huts/hamlets in the 17th century, increased in size over the centuries to a small town in the 18th century, a relatively big town in the 19th century, and assumed a city status in the 20th century, though with a weak economic base due to its predominantly agrarian economy. But with establishment of educational and other institutions in the latter half of the 20th century, and more importantly, establishment of the Ladoke Akintola University of Technology (LAUTECH), in 1990, it has developed in all fronts spatially, socially, economically and otherwise - particularly in the wake of the 21st century to assume a major urban centre status (though with a relatively weak industrial base). The temporal urban growth was not unaccompanied by population increase. The population of the town, which was adapted from various sources and population censuses, was put as 25,000 in $1850 ; 80,000$ in $1911 ; 139500$ in 1952; 166,034 in 1991; 253,282 in 2006; and projected (using 3.2\% growth rate) to 325,869 for 2014 (NPC, 2006). No doubt, the population has increased the more in the last three years.

Of particular interest is the increasing human and/or land use activities that have accompanied the spatial and demographic growth of the town. As observed by Jelili and Adedibu (2006), and characteristic of most Nigerian towns and cities, there has been little and highly inadequate physical planning and development control activity exhibited in the town, leaving most land use activities uncontrolled and unregulated. The resultant effect of this is the increasing growth of informal activities, especially IAWs whose pollution impacts may portend dangers to the health and well-being of the populace.

\section{Data types and sources}

Apart from the secondary data on population obtained from the NPC, and street and other maps adapted from relevant Ministries and Google earth, the study was based mainly on primary data which were obtained on three major aspects, including: (1) spatial distribution of IAWs obtained through physical identification and taking of their rough coordinates for fixing of their locations and mapping; (2) possible effects of the activities of the IAWs on water, soil and air properties as a way of determining the impacts of the activities on the health and well-being of the people; and (3) socioeconomic characteristics of the operators (artisans/technicians).

\section{Data collection and analysis framework}

Ogbomoso is a pre-colonial urban centre with a vast spatial extent that is predominantly residential and that could be divided into different density areas. Each of these density areas exhibits certain features in terms of the type, structure, housing layout and condition, occupancy ratio, and nativity of the residents, thereby reflecting social, economic and cultural attributes (Adeboyejo and Onyenuoru, 2002; Afon, 2007).

In all, three density areas were identified with urban localities in each spreading non-contiguously across different parts of the town. Obtained data (on the effects of the activities on the environment) were aggregated for each of the density areas for inter-density analysis. The inter-density analysis is important to bring about physical planning and policy issues necessary for effective framework for the control of the informal land use.

For the purpose of this study and that of data collection, workshops of the categories below were covered in the survey: (1) fixing of mechanical faults, services and related activities; (2) panel beating; (3) battery charging; (4) car painting, and (5) car rewiring. All the major roads were surveyed for the IAWs in any of these categories and their locations were noted on maps, while their socioeconomic characteristics and other issues were obtained via questionnaire administration to most senior adult identified at the workshops.

For possible air pollution effect, in situ measurements of air samples taken at points where there is uniform flow of gases (that is, during burning, welding points, engine riving, and air-conditioner refilling) at each location using hand held metres, taken at every hour for six hours. Few hours were considered relevant because exposure at short duration affects humans adversely..

Soil samples were collected from 1 to $15 \mathrm{~cm}$ depth, while water samples were collected with plastic containers ( $4 \mathrm{~L}$ each) from well found within a radius of not more than $100 \mathrm{~m}$ from the centre of each of the selected workshops.

In all, six (two from each density area) fully established IAWs were selected for analysis. A fully established IAW is that, which has three or more units of different automobile repair/maintenance services. This is because they usually exist in groups to benefit from agglomeration economies of land rent, security service, and other reduced costs.

\section{Data analysis}

The methods of data analysis used were of two categories. The first one had to do with the physico-chemical properties of air, water, and soil samples, while the second aspect was about the statistical analysis used in summarizing/describing the data and inferential tools used in analyzing the spatial distribution of IAWs and in testing the variation of the physico-chemical properties across density areas.

For ambient air, samples were collected from selected locations and analyzed using hard held air metres to test for the presence and concentrations of $\mathrm{Co}, \mathrm{Co}_{2}, \mathrm{H}_{2} \mathrm{O}$ and $\mathrm{O}_{2}$. These are some of the substances described as "criteria air pollutants" (European Environment Agency - EEA, 2012).

For soil samples, bio-chemical properties like conductivity, nitrate, chloride, sulphate, lead, iron, $\mathrm{pH}$, organic carbon, zinc and cadium were tested for, using standard methods as specified by AOAC (1978) and the laboratory of the Department of Agronomy, University of lbadan. This is to discover which elements exceed the standard soil quality as given by FEPA and WHO.

To test for water quality or extent of pollution in water, it is necessary to examine the presence of trace and heavy metals and its organic content through physico-chemical analysis of water samples for $\mathrm{pH}$, conductivity, total dissolved solids (TSS), dissolved oxygen (DO), total suspended solids (TSS), lead ( $\mathrm{Pb}$ ), cadmium $(\mathrm{Cd})$, iron (Fe), zinc ( $\mathrm{Zn})$, sulphate, nitrate and chloride, using standard laboratory procedures as prescribed by the APHA (1998).

The inferential statistical tools used were: (1) nearest neighbour analysis for the IAWs' spatial distribution analysis, and (2) ANOVA for testing the inter-density variations of the air, soil and water samples.

\section{RESULTS AND DISCUSSION}

The results of the study are presented under different headings to provide answers to such questions as (1) 
how are the IAWs distributed in space; (2) what are the environmental implications of the activities of IAWs; (3) who are the operators (artisans/technicians) of the IAWs?

\section{Spatial distribution of IAWs}

Two things are observable from the results of the spatial distribution (Figure 1). The first one has to do with the fact that nearly all the identified IAWs are directly along major roads, while more are found to be landlocked, for an obvious reason of easy access of the clients motorists. The second thing is about the fact that, with the Nearest Neighbor Index, R, of 0.8654 (that is, less than 1), the distribution is in between clustering and orderliness, whose extreme values are 0 and 1 respectively. With this, and the z-score of 34.23 (which is far greater than +1.96) the hypothesis that "the spatial distribution of IAWs in Ogbomoso is random" is rejected at $95 \%$ confidence level. This is at variance with the observed pattern for Osogbo, a state capital (Jelili, et al., 2017) though of the same geopolitical zone (southwest) of the country. The observed tendency for clustering is not unconnected with the fact that many of the workshops, with different services, co-exist within a large space to benefit from agglomeration economies, and to make use, as squatters in most cases, of the available 'abandoned' properties, the spatial pattern of which can also be observed not to be random in the city. The tendency for orderliness is not unconnected with the quest for maximized market/service radius, which necessitates maintaining a relative distance from another group of IAWs.

\section{Environmental and health implications of IAWs' activities}

The results here are presented on three components of the environment - air, water, and soil. For the soil samples, it is observed that the results for $\mathrm{pH}$ and organic carbon are within permissible levels. For example, while that of $\mathrm{pH}$ in all the localities from different density areas ranges between 6.21 and 7.09 (that is, within the permissible range of 6.0 to 7.5), that of organic carbon lies within a range of 1.53 and $11.02 \mathrm{~g} / \mathrm{kg}$, which is still within a permissible level and could support urban agriculture and soft landscaping. The same permissible conditions are noted for soil's nitrate, chloride, and sulphate, as revealed in Table 1 that the concentrations of nitrate, chloride and sulphate in the soils are 0.10 to $0.2 \%, 3.38$ to $52.50 \%$ and 7.60 to $9.28 \%$ respectively. The situation may be regularly examined and kept under constant check, as it is warned that nitrate contaminated drinking water could have an impact on the size and functionality of thyroid gland in school children (AFAR,
2000).

For heavy metals like lead $(\mathrm{Pb})$ (with values ranging between 14.9 and $830.5 \mathrm{mg} / \mathrm{kg}$, and zinc ( $\mathrm{Zn}$ ) (ranging from 108 to $1337.5 \mathrm{mg} / \mathrm{kg}$ ), however, permissible levels (of 100 and $400 \mathrm{mg} / \mathrm{kg}$ for lead and zinc respectively) have been far exceeded in one of the two places each of the high and medium density areas, except for cadmium (with a score range of 0.35 to $4.0 \mathrm{mg} / \mathrm{kg}$ ); even then, the score range for cadmium is touching the permissible border. Exceeding or touching permissible border like this is a sign of health danger for the people around the place, as toxic heavy metals can accumulate in human tissues for a long time (Kumar, 2007; FEPA, 1991).

Results on water samples (Table 2) indicate varying concentration levels of pollutants. For heavy metals, it is observed that all (lead, cadmium, and zinc) but one (iron) exceed their permissible levels, with lead (Pb), cadmium $(\mathrm{Cd})$, and zinc $(\mathrm{Zn})$ having concentration values ranging between 0.481 to $0.773 \mathrm{mg} / \mathrm{l}, 0.014$ to $0.058 \mathrm{mg} / \mathrm{l}$ and 0.003 to $0.01 \mathrm{mg} / \mathrm{l}$ respectively, while iron $(\mathrm{Fe})$ has a concentration level ranging between 0.002 and 0.012 . It is important to mention that the situation of high concentration levels of some of these heavy metals raises a health concern. For example, cadmium is highly toxic, and many cadmium compounds are also believed to be carcinogenic, the adverse physiological effect of much consumption of it include depressed growth rate, anemia, hypertension, damage to renal tubules and poor mineralization of bones (Lundset et al., 2003).

A similar pattern of exceeding their permissible levels (as prescribed by FEPA and WHO) is also observed from the results on concentration levels of total suspended solids (TSS) and total dissolved solids (TDS), with concentration values ranging between 181.1 to 513.9 $\mathrm{mg} / \mathrm{l}$, and 212.3 to 602.3 respectively. It is important to note that, though, high values of TDS in ground water are generally not harmful to humans, it may affect persons suffering from kidney and heart diseases, while continuous consumption of water with high TDS values may cause gastro-intestinal irritation (Kumaraswamy, 1999; Geetha et al, 2008).

More so, it is observed that while nitrate and sulphate with concentration levels of 1.12 to $2.74 \mathrm{mg} / \mathrm{l}$ and 0.05 to $8.88 \mathrm{mg} / \mathrm{l}$ respectively, are within the permissible level of $250 \mathrm{mg} / \mathrm{l}(\mathrm{WHO})$, chloride with a high concentration level ranging between 90.00 and $918.00 \mathrm{mg} / \mathrm{l}$ exceeds the permissible level. The health implication of this is the tendency of the residents to be disposed to eye irritation, and stomach discomfort, among others.

As an essential determinant of corrosive nature of water (Guptaa, 2009), the $\mathrm{pH}$ values of water samples are observed to range between 7.1 and 8.1 which fall within the FEPA permissible level. This may be put under constant check, as however, abnormal water $\mathrm{pH}$ may cause bitter taste, corrosion, affect mucous membrane and aquatic life. 


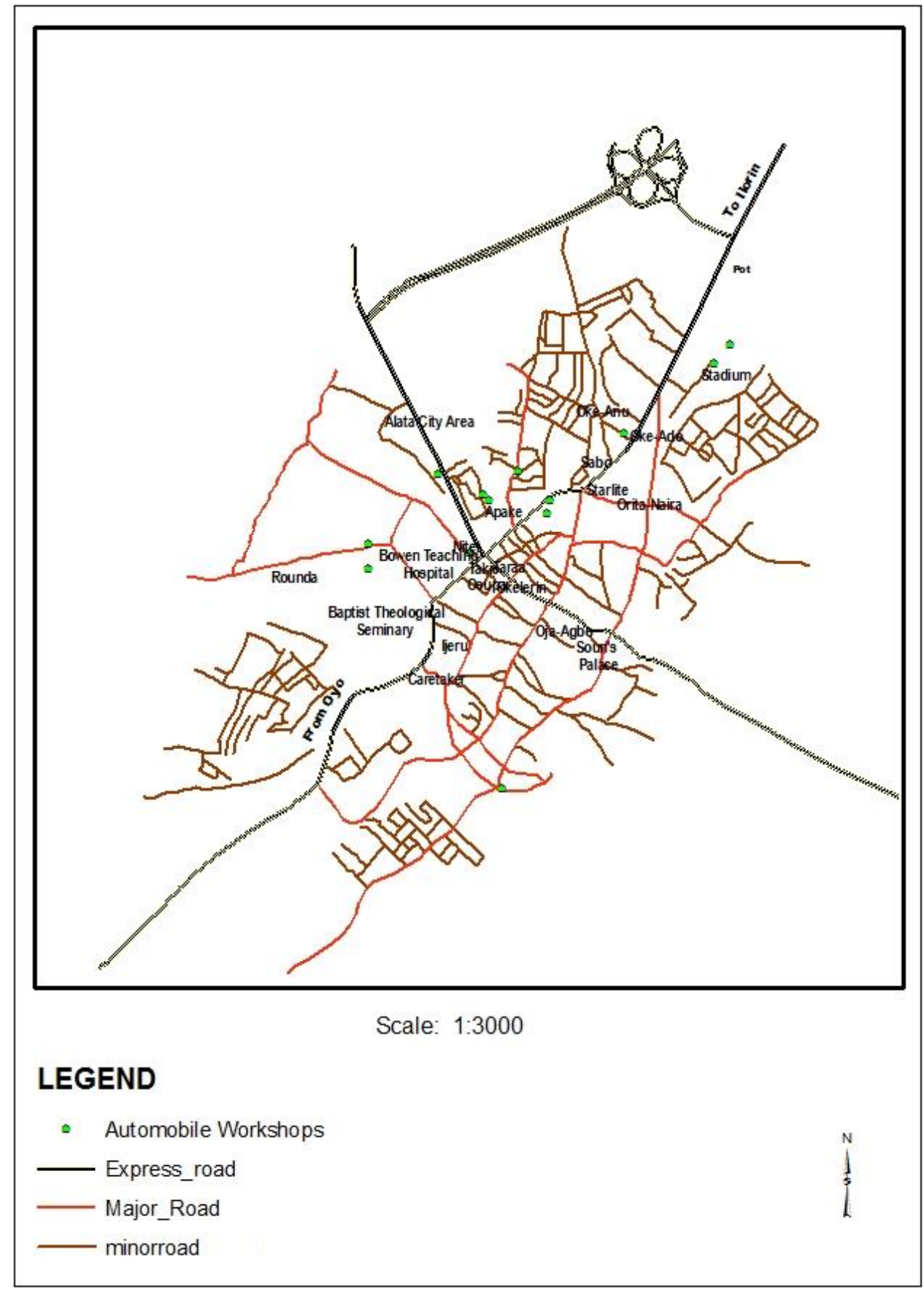

Figure 1. Map of the study area showing recognizable informal automobile workshops. Source: Google Earth and Author's Compilation (2014).

Next in this research are the results on air samples, which indicate the averages of the recorded concentration levels of air pollutants in different density areas and localities. It is observed that Table 3 above shows the results on five gaseous pollutants, with all observed to be relatively high and above the permissible levels of air quality standards. For example, carbon monoxide (CO) is among the major air pollutants in an informal automobile workshop's environment and contributes largely to air pollution in the study area. CO is a good example of a chronically toxic gas. When it bonds to the hemoglobin molecules in red blood cells, the latter 
Table 1. Physicochemical properties of soil samples within/around IAWs in the study area.

\begin{tabular}{|c|c|c|c|c|c|c|c|c|c|c|c|}
\hline Density & Locality & $\begin{array}{c}\text { Conductivity } \\
(\mu \mathrm{s} / \mathrm{cm})\end{array}$ & $\begin{array}{c}\text { Nitrate } \\
\% \\
\end{array}$ & $\begin{array}{c}\text { Chloride } \\
\%\end{array}$ & $\begin{array}{c}\text { Sulphate } \\
\%\end{array}$ & $\begin{array}{c}\mathrm{pH} \text { of } \\
\mathrm{H}_{2} \mathrm{O}\end{array}$ & $\begin{array}{c}\text { Organic } \\
\text { Carbon }(\mathrm{g} / \mathrm{kg})\end{array}$ & $\begin{array}{c}\mathrm{Pb} \\
(\mathrm{mg} / \mathrm{kg})\end{array}$ & $\mathrm{Cd}(\mathrm{mg} / \mathrm{kg})$ & $\mathrm{Fe}(\mathrm{mg} / \mathrm{kg})$ & $\mathrm{Zn}(\mathrm{mg} / \mathrm{kg})$ \\
\hline \multirow{2}{*}{ Low } & Randa 1 & 253 & 0.13 & 3.38 & 9.28 & 6.80 & 8.39 & 55.6 & 3.05 & 71000 & 1320 \\
\hline & Randa 2 & 383 & 0.10 & 31.25 & 9.14 & 6.21 & 9.50 & 14.9 & 1.60 & 26500 & 108 \\
\hline \multirow{2}{*}{ Medium } & Stadium & 373 & 0.18 & 12.00 & 8.63 & 7.01 & 5.61 & 24.1 & 4.00 & 9775 & 118.5 \\
\hline & Arowo-mole & 653 & 0.10 & 13.75 & 8.81 & 6.90 & 5.54 & 460.0 & 0.35 & 21625 & 241.0 \\
\hline \multirow{2}{*}{ High } & Kara & 443 & 0.16 & 52.50 & 8.23 & 6.25 & 1.53 & 24.2 & 2.10 & 24225 & 137.0 \\
\hline & ljeru & 513 & 0.20 & 16.25 & 7.60 & 7.09 & 11.02 & 830.5 & 2.85 & 78500 & 1337.5 \\
\hline \multicolumn{2}{|c|}{ *Permissible level } & & & & & $6-7.5$ & & 100 & & & 400 \\
\hline
\end{tabular}

Source: Authors' Fieldwork (2016); and *permissible levels adapted from FEPA (1991, 1999), AFAR (2000) and Kumar (2007).

Table 2. Physicochemical properties of water samples within/around IAWs in the study area.

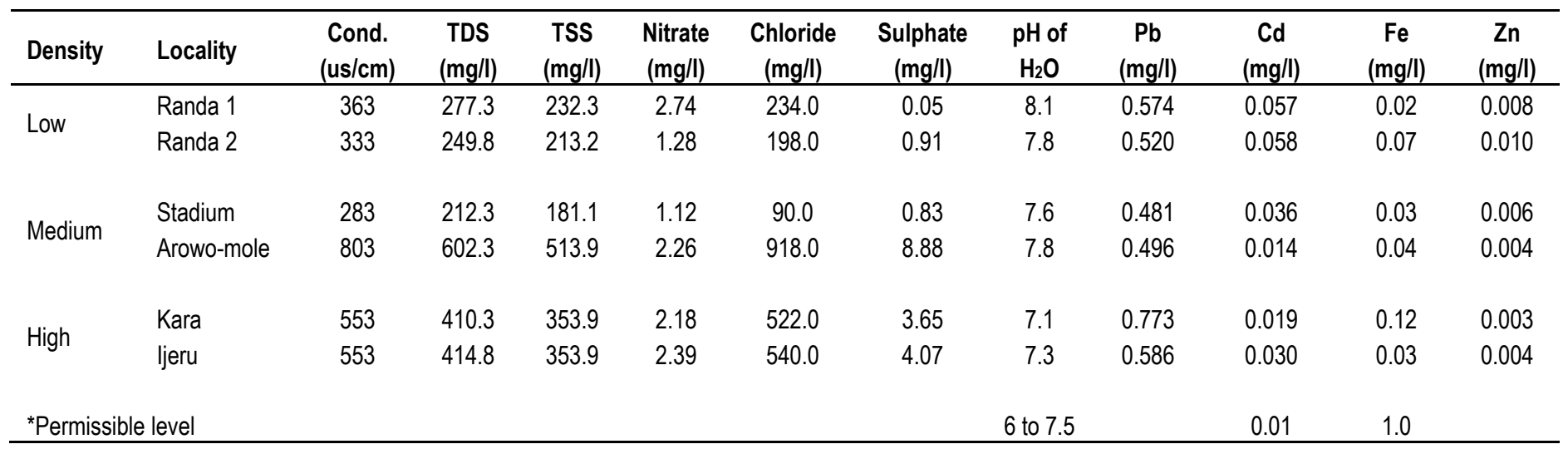

Source: Authors' Fieldwork (2016); and *permissible levels adapted from FEPA (1991, 1999), AFAR (2000) and Kumar (2007).

get contaminated and are unable to transport oxygen, the acute condition of which may lead to respiratory arrest or death.

As observed from Table 4, of all the gaseous pollutants tested, only $\mathrm{CO}_{2}$ and $\mathrm{H}_{2} \mathrm{~S}$, with $\mathrm{p}$-values of 0.001 and 0.01 respectively showing a statistically significant variation in the concentration of each pollutant across density area. As attested to from Table 3 for example, while the concentration of $\mathrm{CO}_{2}$ at an average activity source in low density area is as relatively low as 0.024 $\mathrm{mg} / \mathrm{m}^{3}$, it is as high as $0.058 \mathrm{mg} / \mathrm{m}^{3}$ for a similar activity source in high density area, which is significantly above the overall average of $0.041 \mathrm{mg} / \mathrm{m}^{3}$. Similarly, the observed average values for $\mathrm{H}_{2} \mathrm{~S}$ in low, medium and high density areas are 2.802, 3.570 and $1.61 \mathrm{mg} / \mathrm{m}^{3}$ respectively, as against the overall average of 2.661 $\mathrm{mg} / \mathrm{m}^{3}$. It is, however, important to take caution in generalizing the situation based on these average values.
This is because the relatively high standard deviation value for virtually every gaseous pollutant suggests that a relatively low or high average concentration value may not necessarily mean a high or low concentration of a pollutant for specific activity areas. It rather suggests that each activity area is to be treated based on the type, magnitude, and duration of pollutant-generating activities.

\section{Who are the informal automobile workshops (IAWs)' operators}

The question of who are the IAWs' operators in the study area is attempted here. As noted from Table 5, it is observed that IAWs' operators possess certain socioeconomic characteristics which make it necessary to study their activities, as a land use with implications for urban environment and economy. 
Table 3. Physicochemical properties of air samples within/around IAWs in the study area.

\begin{tabular}{llccccc}
\hline Density & Locality & $\mathbf{C H}_{4}(\mathbf{p p b})$ & $\mathbf{C O}\left(\mathbf{m g} / \mathbf{m}^{3}\right)$ & $\mathbf{C O}_{2}\left(\mathbf{m g} / \mathbf{m}^{3}\right)$ & $\mathbf{O}_{2}\left(\mathbf{m g} / \mathbf{m}^{3}\right)$ & $\mathbf{H}_{2} \mathbf{S}\left(\mathbf{m g} / \mathbf{m}^{3}\right)$ \\
\hline \multirow{2}{*}{ Low } & Randa 1 & 3.12 & 68.0 & 0.02 & 20.0 & 2.69 \\
& Randa 2 & 2.45 & 89.8 & 0.03 & 21.26 & 2.91 \\
& Mean & 2.78 & 78.9 & 0.024 & 20.74 & 2.802 \\
& & & & & & \\
\multirow{4}{*}{ Medium } & Stadium & 2.70 & 47.6 & 0.04 & 20.66 & 4.16 \\
& Arowomole & 1.98 & 73.8 & 0.05 & 20.84 & 2.98 \\
& Mean & 2.34 & 60.70 & 0.042 & 20.75 & 3.570 \\
& & & & & & \\
\multirow{4}{*}{ High } & Kraa & 3.22 & 90.0 & 0.05 & 20.82 & 0.70 \\
& ljeru & 2.14 & 114.6 & 0.07 & 21.02 & 2.52 \\
& Mean & 2.68 & 102.30 & 0.058 & 20.92 & 1.610 \\
& & & & & & \\
Total & Mean & 2.60 & 80.63 & 0.041 & 20.80 & 2.661 \\
& Stand. Dev. & 1.37 & 49.04 & 0.022 & 0.620 & 1.529 \\
\hline
\end{tabular}

Source: Authors' Field Work (2016).

Table 4. Results of inter-density variation analysis (ANOVA) in the gaseous pollutants.

\begin{tabular}{llccccc}
\hline & & Sum of Squares & Df & Mean Square & F & Sig. \\
\hline & Between Groups & 1.064 & 2 & 0.532 & 0.269 & 0.766 \\
$\mathrm{CH}_{4}$ & Within Groups & 53.356 & 27 & 1.976 & & \\
& Total & 54.420 & 29 & & & \\
& & & & & \\
& Between Groups & 8697.867 & 2 & 4348.933 & 1.924 & 0.166 \\
$\mathrm{CO}$ & Within Groups & 61031.100 & 27 & 2260.411 & & \\
& Total & 69728.967 & 29 & & & \\
& & & & & & \\
& Between Groups & 0.006 & 2 & 0.003 & 10.067 & 0.001 \\
$\mathrm{CO}_{2}$ & Within Groups & 0.008 & 27 & 0.000 & & \\
& Total & 0.014 & 29 & & & \\
& Between Groups & 0.205 & 2 & 0.102 & .252 & 0.779 \\
$\mathrm{O}_{2}$ & Within Groups & 10.945 & 27 & 0.405 & & \\
& Total & 11.150 & 29 & & & \\
& Between Groups & 19.508 & 2 & 9.754 & 5.453 & 0.010 \\
$\mathrm{H}_{2} \mathrm{~S}$ & Within Groups & 48.293 & 27 & 1.789 & & \\
& Total & 67.801 & 29 & & & \\
\hline
\end{tabular}

Source: Authors' Analysis (2016).

Table 5 shows that all (100\%) IAWs' operators in Ogbomoso are male and married, majority of whom $(70.9 \%)$ are youths in their thirties, including 37.5 and $33.4 \%$, aged between 31 to 35 and 36 to 40 respectively. Most $(70.8 \%)$ of them secondary school leavers, with majority $(70.8 \%$, that is, $33.3+37.5 \%)$ of them earning

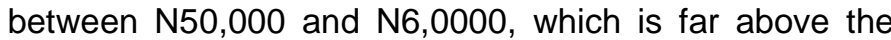
national minimum of $\mathrm{N} 18,000$. This has perhaps enabled them to maintain a household size ranging between 4 and 8 , with most $(91.6$, that is, $25+45.8+20.8 \%)$ of them having a household size of 4 to 6 . With the highlighted socioeconomic variables, it becomes crystal 
Table 5. Socioeconomic characteristics of IAWs' operators.

\begin{tabular}{|c|c|c|}
\hline Socioeconomic variable & Category & $\%$ \\
\hline \multirow{2}{*}{ Gender } & Male & 100 \\
\hline & Female & 0.00 \\
\hline \multirow{2}{*}{ Marital Status } & Single & 0.00 \\
\hline & Married & 100.00 \\
\hline \multirow{7}{*}{ Age Group } & $18-30$ & 0.00 \\
\hline & $31-35$ & 37.5 \\
\hline & $36-40$ & 33.4 \\
\hline & $41-45$ & 12.5 \\
\hline & $46-50$ & 08.2 \\
\hline & $51-55$ & 08.4 \\
\hline & 56 and above & 00.0 \\
\hline \multirow{3}{*}{ Educational Level } & Less than Secondary & 00.00 \\
\hline & Secondary & 70.80 \\
\hline & Tertiary education & 29.20 \\
\hline \multirow{6}{*}{ Income } & Less than 20,000 & 00.00 \\
\hline & $21,000-30,000$ & 08.30 \\
\hline & $31,000-40,000$ & 20.80 \\
\hline & $41,000-50,000$ & 33.3 \\
\hline & $51,000-60,000$ & 37.50 \\
\hline & Above 60,000 & 00.00 \\
\hline \multirow{5}{*}{ Household Size } & Less than 3 & 00.00 \\
\hline & $3-4$ & 25.00 \\
\hline & $5-6$ & 66.60 \\
\hline & $7-8$ & 08.30 \\
\hline & Above 8 & 00.00 \\
\hline
\end{tabular}

Source: Authors' Fieldwork (2016).

clear that the IAWs' operators are mostly heads of households, bread winners, service providers, and thereby, constitute an important urban and/or socioeconomic subpopulation, which need be properly accommodated in the urban economy and land use planning, rather than discriminated against.

\section{CONCLUSION AND RECOMMENDATIONS}

Informal automobile workshops are an important category of urban land use in most Nigerian towns and cities, exemplified in Ogbomoso, and as such cannot be left out in the scheme of things - urban land use and economic planning. The unregulated nature of the land use has, however, been of concern for long, and has made the impact (both positive and negative) to be less studied and understood compared to other categories of urban land use especially those in the formal economy. This has necessitated the need for more attention on the land use category, particularly the acclaimed associated impacts with and on the urban environment.

This study has been able to establish the fact that the spatial distribution of the land use is not random, but concentration along major roads and at certain intervals which may not be quite regular, because spaces/buildings occupied are usually not pre-allocated for IAWs, but usually spring up as squatter land use, which has a lot of negative impacts for the environment. Such impacts, though varying in magnitude with type of pollution (air, water, soil) and density area where an IAW is found, depends on the nature and duration of activity of 
specific informal workshops.

Given the importance of the services they render for the populace, and the fact that the operators are responsible household heads who also contribute significantly to the urban economy, the land use category ought to be accommodated in the urban economy. The health implication may however portend danger if it is not formally integrated into land use planning.

It is the view of this paper that the process of formalizing business outfits including registration, land acquisition, development permit, among others shall be made simpler for such category of land use to remove the bottlenecks and other hindrances which may prevent the relatively less economically buoyant operators of the IAWs, among similar categories of land use activities. This may include a policy or policies encouraging waivers in some development control and registration processes in favour of IAWs as a land use, and informal land use activities in general.

It is equally suggested that further studies be geared towards addressing different dimensions of the complexity that such process of integration may entail. From such studies, there should be, among others, evolvement of a classification scheme that would recognize different categories of informal land use activities.

\section{CONFLICT OF INTERESTS}

The authors have not declared any conflict of interests.

\section{REFERENCES}

Adeboyejo AT, Onyenuoru I (2002). Urban Residential Density and Adolescent Sexuality and Reproductive Health in Oyo State, Nigeria. A report submitted to the Union of African Population Studies (UAPS) Dakar, Senegar.

Adewoyin OA, Hassan AT, Aladesida AA (2013). The Impacts of AutoMechanic Workshops on Soil and Ground Water in Ibadan Metropolis. African Journal of Environmental Science and Technology 7(9):891-898.

AFAR (2000). Agriculture, food and rural revitalization micronutrients in crop production in Saskatchewan, Canada, Update. pp.1-30.

Afon AO (2007). An analysis of solid waste generation in a traditional African city: the example of Ogbomoso, Nigeria. Environment and Urbanization 19(2):527-537.

American Public Health Association (1998). Standard Methods for Examination of Water and Wastewater, $20^{\text {th }}$ Edition, APHA, Washington, DC. P 1134.

Bassuer G (1987). The endangered ozone layer and new theories of ozone depletion. Journal Environment Science 29(1):20-27.

European Environment Agency (EAA) (2012). European Union Emission Inventory Report 1990-2010 under the UNECE Convention on Long-Range Transboundary Air Pollution (LRTAP). Available at: https://library.wmo.int/index.php?|vl=notice_display\&id=12741\#.YCK Uv7BKiM8

Ekong FU, Michael GUS, Michael US (2012). Assessing the effects of mechanic activities on Uyo air environment. Ethiopian Journal of Environmental Studies and Management 5(1):74-85.
Essaghah A (1997). Urban Planning Concepts, Standards and Symbols. Lagos: Amfitop Books Nigeria Ltd.

Faronbi AG, Adebayo OR, Oyekanmi AM (2013). Impact of Petroleum Product on the Soil around Automobile. IOSR Journal of Applied Chemistry 4(1):13-15.

FEPA (1991). National Guidelines and Standards for Water Quality in Nigeria, Federal Ministry of Environment. P 114

Geetha A, Palanisamy PN, Silvakumar P, Kumar PG, Sujatha M (2008). Assessment of Underground Water Contamination and Effect of Textile Effluents on Noyyal River Basin in and around Tiruppur Town, Tamilnadu. E-journal of Chemistry 5(4):696-705.

Gupta D, Sunita P, Saharan JP (2009). Physiochemical Analysis of Ground Water of Selected Area of Kaithal City (Haryana) India. Researcher 1(2):1-5.

Ipeaiyeda AR, Dawodu M (2008). Heavy Metals Contamination of Topsoil and Dispersion in the Vicinities of Reclaimed Auto-repair Workshops in Iwo Nigeria. Bulletin of the Chemical Society of Ethiopia 22(3):339-348.

Iwegbue CM (2007). Metal fractionation in soil profiles at automobile mechanic waste dumps. Waste Management and Research 25(6):585-593

Jelili MO, Adedibu AA (2006). Land use classification and informal sector question in Ogbomoso. Journal of Human Ecology 20(4):283287.

Jelili MO (2012). Urbanization and Future of Cities in Africa: The Emerging Facts and Challenges to Planners. Global Journal of Human-Social Science 12(7):7-12.

Jelili MO, Olanrewaju SO, Odunola OO (2017). Spatial distribution and landuse planning of informal automobile workshops in Osogbo, Nigeria. Ethiopian Journal of Environmental Studies and Management 10(1):112-24.

Juhasz C, Szollosi N (2008). Concept of Environmental Management in India. Environmental Protection (Debreceni Egyetem a TÁMOP 4.1.2 pályázat keretein belül) Available at: https://regi.tankonyvtar.hu/hu/tartalom/tamop425/0032_kornyezetiran yitas_es_minosegbiztositas/ch03.html

Kayemuddin M, Kayum S (2013). Problems and prospects of automobile workshops in Bangladesh. Journal of African Studies and Development 5(6):157-162.

Nwachukwu MA, Feng H, Alinnor J (2010). Assessment of heavy metal pollution in soil and their implications within and around mechanic villages. International Journal of Environmental Science and Technology 7(2):347-358.

Okeke DC (2000). Urban Land Use Planning and Informal Sector Syndrome: A case study of Enugu. Journal of the Nigerian Institute of Town Planners 13:56-65.

Onyebueke VU (2000). Incidence of Informal Sector Enterprises in the Urban Residential Zone: Analysis of the Pattern and Determinants in Enugu. Journal of the Nigerian Institute of Town Planners 13:1-25.

Onyebueke V, Geyer M (2011). The informal sector in urban Nigeria: Reflections from almost four decades of research. SSB/TRP/MDM. P 59.

Utang PB, Eludoyin OS, ljekeye CL (2013). Impacts of Automobile Workshops on Heavy Metals Concentrations in Urban Soils in Obio/Akpor LGA, Rivers State, Nigeria. African Journal of Agricultural Research 8(26):3476-3482.

Uchegbu SN, Umeh LC (1998). Principles and Procedures of Environmental Impacts Assessment. Enugu: Computer Edge. P 342.

Wong MH, Lau W (1985). Root Growth of Dicotlidone and Eleusine Indicia collected from motorways at different concentrations of Lead, Environmental research Report 38:257-267. 